\title{
How to Show That Christian Theism is True: A Call to the Next Generation of Christian Apologists
}

\author{
Lataster $\mathrm{R}^{*}$ \\ The University of Sydney, Australia
}

*Corresponding author: Raphael Lataster, PhD, The University of Sydney, Woolley A20, NSW, Australia, Email: raphael.lataster@sydney.edu.au

\section{Conceptual Paper}

Volume 2 Issue 2

Received Date: February 21, 2019

Published Date: April 10, 2019

DOI: $10.23880 /$ phij-16000116

\section{Abstract}

It is one thing to know that Christian theism is true. It is another thing altogether to show that Christian theism is true**. Building on the recent work of theistic and atheistic philosophers of religion, I briefly explain the (near) ideal way to go about demonstrating the truth or likelihood of Christian theism to non-believers. Whilst generally trying to avoid making the much-sought probabilistic judgements, I explain the many steps involved in firstly arguing that theism is the superior hypothesis, and then arguing that the Christian interpretation of theism is the best one. Realising the enormity of the task, I also offer some practical advice for this important work.

Keywords: Theism; Naturalism; Polytheism; Deism; Pantheism; Panentheism; Pandeism

** We shall put aside discussions about fideism, which I do, of course, accept as a valid option.

\section{The (Probably) Best Way to Argue}

Christian theists typically have many and varied reasons for believing as they do, but these reasons are not always convincing to the non-believer. The latter generally will require evidence and argumentation in order to be convinced of the truth of Christian theism (CT). Several books dedicated to arguing for and against CT seem to at least agree that the ideal way to approach the problem, perhaps short of somehow invoking the god of CT (God) to reveal itself directly to every non-believer, is to present a probabilistic case ${ }^{1}$. The only other options

1For example, see Richard Swinburne, The Coherence of Theism, 2nd ed. (Oxford: Oxford University Press, 2016); Herman Philipse, God in the Age of Science?: A Critique of Religious Reason (Oxford: Oxford University Press, 2012); Raphael Lataster, The Case Against Theism: Why the Evidence Disproves God's Existence (Cham, Switzerland: Springer, 2018). are: to argue from certainty, which is unrealistic, even if only because of the justifiable uncertainties about our cognitive ability to arrive at or convincingly argue for certainty about things, and would almost always be heavily doubted by incredulous non-believers; ${ }^{2}$ or to argue from possibility, which is unhelpful, as a great many hypotheses are possibly true, and the only real benefactor would be the agnostic.

And the most promising way to argue probabilistically is to use the Bayesian probability calculus, as endorsed by respected philosophers of religion such as Richard Swinburne (a Christian theist) and Herman Philipse (a

\footnotetext{
${ }^{2} \mathrm{~A}$ useful primer on the Cognitive Science of Religion, though it also focuses on the implications for New Testament research, is István Czachesz, Cognitive Science and the New Testament: A New Approach to Early Christian Research (Oxford: Oxford University Press, 2017).
} 
naturalist). This involves weighing up the prior probabilities of our hypotheses against the likelihoods, which should allow us to proclaim which hypotheses are probably true, based on the currently available evidence. All this means that the much-loved syllogisms are out. If they are framed as deductive arguments, they have no place in a probabilistic analysis. And if they are framed as probabilistic arguments, they are redundant, and even untransparent or outright confusing; for the ideal approach is to directly weigh up each piece of evidence that supports the argument's premises with the various hypotheses.

Those opposed to the use of a numerical approach, will need to find some way to push through, given the aforementioned unrealistic and unhelpful alternatives. But they also need not fear, even in situations where numbers cannot even be reasonably approximated, as a probabilistic analysis can effectively be performed nonquantitatively. So long as analyses have reasonable limitations, relative probabilities are sufficient, and they can be expressed qualitatively. An example would be Graham Oppy's recent book arguing for naturalism over theism $^{3}$. He argues 'from dominance', claiming that naturalism is more modest and better explains the available evidence. While he himself might deny that his approach is Bayesian, his point about modesty easily translates to the ratio of prior probabilities, and his point about better explaining the evidence easily translates to the ratio of likelihoods. If both favour one theory, which thus 'dominates', numbers are for the most part unnecessary as the point is well made ${ }^{4}$.

Much more can be said about the probabilistic approach, but since arguing from certainty is extremely difficult and at least considered dubious by the typical skeptic, and arguing from possibility achieves nothing useful for evangelistic purposes, it is here considered difficult as it may be - as the only way forward. Thankfully, we can opt to divide and conquer by cleaving our task in two. Let us first look at how we can prove theism, before we argue for a Christian form of theism.

\section{Arguing For Theism}

What may seem like a daunting task is actually very simple, at least conceptually. Regarding our likelihoods, each bit of evidence needs to be judged as being more,

${ }^{3}$ Graham Robert Oppy, The Best Argument Against God (Melbourne: Palgrave Macmillan, 2013).

4This is elaborated in Lataster (TCAT). less, or just as likely on theism. For example, in a nod to cosmological and teleological arguments, we might decide that the Big Bang and the apparent fine-tuning of the universe are more likely if theism is true. And, in a nod to some of the classic arguments against theism, we might decide that the presence of gratuitous evil and the seemingly unnecessary vastness of the universe are more likely on naturalism. An arduous task to be sure, but this must be done for every relevant piece of evidence. However, this big task is about to become even bigger, which goes some way to explaining why this article is concerned with how to argue for the truth of CT and not concerned with actually arguing for the truth of CT - I shall leave that for my colleagues, or at least for another day!

The complicating issue in arguing for the truth of theism is that we ought not simply compare theism with naturalism. If naturalism is our $p$, then our 1- $p$, or $q$, is not theism. It is supernaturalism. Theism is but one of many supernaturalistic hypotheses. It is clear then that comparing only theism and naturalism, while interesting, is not sufficient. If we are to demonstrate that theism is probably true, we need to compare it with naturalism and the many alternative supernaturalisms. Unfortunately, there are a great many supernaturalistic alternatives that we must contend with.

One group of alternatives is the polytheisms. Polytheism is generally taken to be the belief in many gods, but it is not precisely a hypothesis; it is a 'catch-all' hypothesis. One polytheistic hypothesis says that there are two gods. Another says that there are three. Yet another asserts the existence of four. However ridiculous it may sound, another polytheistic hypothesis declares that there are one billion and one gods. Ad infinitum.

Another group of supernaturalistic hypotheses would be the alternative monotheisms. Just as theism is not the only form of supernaturalism, it is also not the only form of monotheism. While theism tends to revolve around a perfect god, many alternative monotheisms posit imperfect or sub-maximal gods. A particularly interesting, and historically important, alternative monotheism would be deism, especially with its implications for the argument from hiddenness. The deistic god is one that does not intend to reveal itself, so could be judged as being a better fit for the 'evidence of hiddenness'. There are also scholars who have posited what can be described as 'quasi-deisms', hypotheses entailing the existence of a revelatory god, but where the revelation is not directed at humankind. 


\section{Philosophy International Journal}

With the previous models entailing a properly transcendent god or gods, yet another group of alternative supernaturalisms is the monisms. This includes pantheism, panentheism, pandeism, and so forth. Essentially any model of the divine that does not involve a substantially transcendent god or gods, but posits monism: the world is or is a part of god. Thankfully, there is increasingly an impressive literature on the topic of panentheism especially. We must also realise that just as with 'polytheism', terms such as 'deism' and 'panentheism' actually refer to sets containing multiple hypotheses.

Insofar as wanting to argue for the truth of theism, we clearly have our work cut out for us. And we have so far only considered likelihoods. We must not forget about the prior probabilities. For example we might say that monotheistic hypotheses have favourable priors over polytheistic theories, on account of relative simplicity, and then might decide that various naturalisms and monisms are simpler still. Or perhaps we can declare the prior probabilities to be inscrutable, which would end our probabilistic analysis before it begins, or at least consider them equal, so that we need only work with the likelihoods. This is certainly not ideal, but it may make for a more achievable job. Arguing for the truth of theism is clearly a monumental task, and perhaps it could be simplified further if certain groups were ruled out for logical impossibilities. For example, the many polytheisms could be instantly eliminated from the calculations if it were proven that there could only be one god. This is of course very difficult, but any successes here would drastically simplify the analysis.

\section{Arguing for Christian Theism}

Once we have proven the truth of theism, we must then convince the rational non-believer that some Christian form of theism is true. There are many hurdles here that must be overcome. Perhaps the first is the many issues around Judaism. While most or all religions are influenced by others, Christianity is open about effectively being a 'spin-off' of Judaism. So apart from explaining why this spin-off was necessary, when pre- and post- secondtemple Jews were happily adhering to their religion/s without needing to accept Christ, we must defend Judaism, at least in part. Judaism and the Old Testament (OT) has been under intellectual attack for some time, with even most Jews now essentially being secular Jews, atheists that are still culturally Jewish but no longer believe the central claims of their own Holy Texts. OT scholars almost unanimously deny that the Torah was written by Moses, pointing to the many sources and cultural challenges that likely influenced it. Many, the OT minimalists, who are now mainstream in biblical research, even doubt that Moses and the patriarchs existed as historical figures, and also doubt central biblical claims such as that the Exodus occurred and that the Jews conquered the Holy Land from the unrelated Canaanites. And even many Catholic leaders are starting to believe that the tale of Adam and Eve is a myth. Furthermore, it is becoming increasingly accepted by scholars that early Judaism was actually polytheistic rather than mono/theistic, with Yahweh finding his way into the Canaanite/Israelite pantheon and gradually becoming the dominant god, and eventually the only god, of the Jews ${ }^{5}$.

Whether or not some form of Judaism has been adequately defended, we inevitably will want to demonstrate the truth of Christianity. Somewhat similar challenges must be overcome, with much of the mainstream work on the New Testament (NT), denying the Gospels' traditional authors, noting influence from Pagan sources, and identifying much of the NT as fraudulent if not otherwise ahistorical 6 . The emerging research on cognitive science has also posed some challenges for the reliability of the NT texts, due to questions about memory reliability and cognitive biases ${ }^{7}$. There is even a small but growing group of scholars, let us call them NT minimalists, that argue that Jesus did not exist as a historical figure - with many of the mainstream scholars who find that conclusion absurd still denying most of the NT's crucial claims about Christ (regarding miracles and divinity). This is an obvious challenge, as any defence of Christianity worth having will undoubtedly point to some miraculous claim found in the Bible. And there is no miraculous claim more crucial to the mainstream forms of the faith than the resurrection of Christ.

One would be forgiven for thinking that I shall now explain the many challenges in arguing for or from miraculous claims, but I think that is a debate we can effectively side step, to an extent. We needn't defend miraculous claims in general, or even define what a miracle is; we need only defend Christ's resurrection as a historical event. Atheists might cry foul, but we are only

\footnotetext{
${ }^{5}$ For example, see Mark S. Smith, The Origins of Biblical Monotheism: Israel's Polytheistic Background and the Ugaritic Texts (Oxford: Oxford University Press, 2001).
}

${ }^{6}$ For example, see Bart D. Ehrman, The Orthodox Corruption of Scripture: The Effect of Early Christological Controversies on the Text of the New Testament, 2nd ed. (Oxford: Oxford University Press, 2011).

${ }^{7}$ Czachesz (CSNT). 


\section{Philosophy International Journal}

truly required to defend the one 'miracle'. If we can prove that the god of theism raised Jesus, who advocated for a 'reformed' Judaism, from death, then we will have gone some way to demonstrating the truth of CT.

I suspect that the best way to defend the historicity of this particular momentous event is to employ the 'minimal facts approach', as endorsed by the likes of Gary Habermas and William Lane Craig8. The first step with this approach is to isolate certain historical facts from the available sources that even atheists can agree with, such as that there were indeed early Christians who literally believed that Jesus died and came back to life, and that some followers claimed to have experienced the risen Christ. Then, remembering our Bayesian approach, such evidence must be weighed up amongst the various hypotheses, which would typically include: Jesus really did arise, some disciples stole the body leading people to think that Jesus was raised, the Gospel authors wrote allegorically and their writings were only later misunderstood as literal, the early believers were merely hallucinating due to their cognitive dissonance and superstitious natures, and so forth. Prior probabilities must also be factored in here. We could, for example, consider how frequently resurrection claims are veridical, and how frequently such claims are fabricated.

Once it has been established that Jesus probably did come back to life, the next step is to argue that God is the one who raised him. Alternative hypotheses of the naturalistic sort, may include, though they may sound ridiculous, the possibility that Jesus wasn't really dead so while he did rise no genuine resurrection took place, and the possibility that some rare mutation allowed Jesus to spark back to life. Hypotheses around alien interventions (some have actually posited this!) could instantly be dismissed for having absurdly low priors, as well as zero direct evidence. Alternative hypotheses of the supernaturalistic sort could include the speculative thesis that Satan raised Jesus, and the atheists could point to numerous warnings in the NT about demonic influence on Earth and false prophets/teachings. We could also consider if some alternative god raised Jesus, but we have at this stage already accepted the truth of theism. Note also that some god's existence surely makes Jesus' resurrection more likely, as even atheists would be inclined to agree, reinforcing the importance of first establishing that theism is true or probably true.

\footnotetext{
${ }^{8}$ See Gary R. Habermas and Michael Licona, The Case for the Resurrection of Jesus (Grand Rapids, MI: Kregel Publications, 2004).
}

Once it has been demonstrated that the god of theism raised Jesus from death, seemingly endorsing his claims and teachings, our task is effectively complete. There are arguably some auxiliary jobs, such as arguing for exclusivism, and refuting similar claims from other religions. There is also the matter of the trinity, whether the evidence supports the view that there is God the Father, God the Son, who is also the Logos, and God the Holy Spirit, a figure often seen by non-trinitarians as the active force or spirit of God; there are other theists, such as mainstream Jews and Muslims, who do not believe that God is effectively made up of three persons. However, I think the non-believer would be hard-pressed to object when shown that the god of theism does exist, and he has specifically and unambiguously backed Jesus Christ, as well as demonstrated the truth of many of the central claims of Christianity.

And that is how it is done. Or how it should be done, anyway.

\section{Concluding Thoughts}

This paper asserts that the best way to show nonbelievers that Christian Theism (CT) is true is to conduct a comprehensive probabilistic analysis, because arguments from certainty are nigh-on impossible and would likely be rejected immediately by those clearly predisposed to skepticism, and arguments from possibility lead to agnosticism at best ${ }^{9}$. We start proper by demonstrating the truth of theism, which necessitates not only contending with naturalistic hypotheses, but also other supernaturalistic hypotheses. This alone is laborious, due to the sheer number of alternatives. Once theism is established, we can move on to proving CT, with a competent defence of the biblical texts and the historicity of a remarkable biblical claim being very much necessary.

Some may object that this endeavour is extraordinarily hard, and it is. But it is the only rational and objective way to compel reasonable non-believers to adopt Christian theism. A bigger criticism would be that this has already been done, pointing to the work of luminaries such as Swinburne. This is not entirely correct. While Swinburne's life work is commendable, Christian scholars need to do much more to argue for the historicity of Christ's resurrection. Due to the nature of this claim, the prior probabilities ostensibly favour alternative hypotheses - a fact we will simply have to accept; honesty

\footnotetext{
${ }^{9}$ Why 'at best'? For one, while the Christian might argue from mere possibility, some intellectual adversary, like the Muslim, might argue from probability, earning a head start.
} 


\section{Philosophy International Journal}

around this issue can only progress the discussion. This is an unfortunate paradoxical truth about resurrection claims, and miraculous claims in general. Such claims have the power to convince and inspire people to change their lives just because they have such an apparent air of implausibility about them, because they seem pretty much impossible, and yet we are obliged to somehow convince non-believers that such an event actually occurred in history. All is not lost, however, as our case can, at least in principle, be salvaged by superior likelihoods. Given the increasing criticisms levelled at the NT texts, much more (than simply expecting skeptics to accept such things unless there is definitive proof to the contrary) needs to be done to show that there are genuine historical truths within them that make Jesus' resurrection very likely indeed.

On the issue of a bare theism, even Swinburne - and others, like Craig - too casually brushes aside supernaturalistic alternatives to theism, and even then he - and others - considers only a handful. For instance, Swinburne's books barely mention the polytheisms and some of the alternative monotheisms, and do not acknowledge many of the monistic hypotheses. Indeed, neither Swinburne, Craig, or any other Christian philosopher I am aware of, makes any mention of pandeism. What is needed is a recognition that there are a multitude of naturalistic and supernaturalistic alternatives to theism, and a comprehensive analysis that decisively reveals theism to be the most probable hypothesis (where the probability is the greatest of all the hypotheses), if not absolutely probable (where the probability is greater than 0.5). Such a task is too momentous to be tackled in this short paper, and it is otherwise impossible for me to even attempt it at this stage of my academic and spiritual journey. I do, however, encourage the emerging generation of young Christian scholars to pick up the baton. Godspeed! 